\title{
Prolonged survival of the Graafian follicle and fertilization in the Japanese greater horseshoe bat, Rhinolophus ferrumequinum nippon*
}

\author{
Y. K. Oh†, T. Mōri and T. A. Uchida \\ Zoological Laboratory, Faculty of Agriculture, Kyushu University 46-06, Fukuoka 812, Japan
}

\begin{abstract}
Summary. After the mating season of the Japanese greater horseshoe bat in mid- or late October, only the right ovary maintained a single Graafian follicle throughout hibernation until early April. During this time the ovum was in prophase of meiosis I (resting stage) with many large lipid droplets as a nutrient source. In synchrony with stigma formation, there was resumption of meiotic activity, separation of the cumulus oophorus from the granulosa layer and dispersion of the follicle cells just before ovulation in spring. The block to polyspermy seemed to reside in the zona pellucida, because no spermatozoa could be detected in the perivitelline space of the 6 fertilized ova examined, although a second spermatozoon was recognized in the zona pellucida of 3 ova.
\end{abstract}

\section{Introduction}

In temperate-zone rhinolophids such as the greater horseshoe bat (Rhinolophus ferrumequinum) and the lesser horseshoe bat ( $R$. hipposideros), such reproductive phenomena as sperm storage in the oviduct during hibernation, formation of the huge vaginal plug and sperm elimination from the female reproductive tract (Fries, 1879; Matthews, 1937; Racey, 1975; Mōri, Oh \& Uchida, 1982; Oh, Mōri \& Uchida, 1983; Uchida, Mōri \& Oh, 1984) have been demonstrated by light or electron microscopy. However, there have been no ultrastructural studies on the prolonged survival of the Graafian follicle and fertilization in rhinolophid bats, although the above processes in both species of horseshoe bats have been shown histologically by Matthews (1937). The aim of the present study was to examine in detail with the electron microscope the morphological changes of the ovum in the surviving Graafian follicle, the development of the fertilized ovum and block to polyspermy in Japanese greater horseshoe bats ( $R . f$. nippon).

\section{Materials and Methods}

Twenty-seven adult females were collected at caves in the Fukuoka, Kumamoto, Yamaguchi and Hyogo Prefectures during the period from immediately before copulation (mid-October before hibernation) to the early developmental stage of the ovum (mid-April after arousal) in 1969-1983 (see Table 1). On the day of or after capture, control bats (Group C, not injected with hormones) were killed by decapitation or perfused under ether anaesthesia through the dorsal aorta with $3 \%$ glutaraldehyde in $0.2 \mathrm{M}$-phosphate buffer ( $\mathrm{pH} 7 \cdot 4$ ). Out of 15 bats captured in April, gonadotrophic hormones were administered at once to 11 (Group G) to induce ovulation, as follows: about $48 \mathrm{~h}$ after a subcutaneous injection of 5 i.u. PMSG (Teikoku-zōki Pharmaceutical Co., Ltd, Tokyo), 2 i.u. hCG (Mochida Pharmaceutical Co., Ltd, Tokyo) were also administered subcutaneously; about $24 \mathrm{~h}$ later the bats were dealt with as described for Group C.

* Reprint requests to Professor T. A. Uchida.

$\dagger$ Present address: Department of Biology, Yonsei University Wonju College, Wonju 220, Korea. 
The reproductive organs were removed and then the tissues were promptly placed in cold $3 \%$ glutaraldehyde in $0.2 \mathrm{M}$-phosphate buffer ( $\mathrm{pH} \mathrm{7.4)}$ ) for $4 \mathrm{~h}$. After being thoroughly rinsed with the same buffer, the tissues were post-fixed with $1.3 \%$ osmium tetroxide in the same buffer, dehydrated with acetone and embedded in Epon 812 . Thick serial sections $(1.5 \mu \mathrm{m})$ for light microscopy were stained with $0.5 \%$ toluidine blue. Thin sections $(\sim 60 \mathrm{~nm})$ were then taken from suitable thick sections mounted on the facet of another prepared Epon block by the method of Oura \& Usuku (1976), and double stained with uranyl and lead acetate before examination in an Hitachi HS-9 electron microscope $(75 \mathrm{kV})$. The reproductive organs fixed with $10 \%$ formalin from Bats C9, G2 and G6 were embedded in paraffin wax and stained with Harris' haematoxylin and eosin.

\section{Results}

The morphological changes of the Graafian follicle during the period of its prolonged survival and the process of fertilization are described separately according to the following four reproductive stages - copulatory, preovulatory without the stigma, preovulatory with the stigma, and fertilized stage (Table 1).

\section{PLATES 1-4}

Abbreviations: A, acrosome; Al, ampullar lumen; An, antrum; $\mathrm{C}$, cortical granule; $\mathrm{Cc}$, cumulus cell; $\mathrm{Cr}$, cell of corona radiata; $\mathrm{E}$, egg; Em, egg plasma membrane; Es, equatorial segment; Fp, first polar body; Fpn, female pronucleus; G, Golgi complex; Gc, granulosa cell; $\mathrm{I}$, incorporation cone; Ia, inner acrosomal membrane; Is, intercellular space; L, lysosome; Ld, lipid droplet; $\mathrm{M}$, mitochondrion; $\mathrm{Mp}$, middle piece; $\mathrm{Mpn}$, male pronucleus; $\mathrm{Mv}$, microvilli; $\mathrm{Mz}$, mitochondrial zone; $\mathrm{N}$, nucleus; Oa, outer acrosomal membrane; $\mathrm{Pa}$, postacrosomal sheath; Se, smooth endoplasmic reticulum; Sm, sperm plasma membrane; Sn, sperm neck; Z, zona pellucida.

\section{PLATE 1}

Fig. 1. Electron micrograph of an egg in a Graafian follicle at the copulatory stage, showing its ectoplasm crowded with abundant spherical mitochondria and large lipid droplets (Bat C15). Inset: light micrograph showing the egg with a mitochondrial zone in the prophase of the meiosis I (resting stage), cumulus oophorus joined to the granulosa layer and undispersed cumulus cells.

Fig. 2. Electron micrograph of the corona cells of the same cumulus oophorus as in Fig. 1 (inset), showing considerable smooth endoplasmic reticulum with expanded cisternae, narrow Golgi field, mitochondria with few cristae, and a few lysosomes and lipid droplets. Inset: higher magnification of smooth endoplasmic reticulum.

\section{PLATE 2}

Fig. 3. Median section through a Graafian follicle at the preovulatory stage with the stigma, showing separation of the cumulus oophorus from the granulosa layer and dispersion of the cumulus cells, which are synchronized with expulsion of the first polar body (Bat G7).

Fig. 4. Electron micrograph of an egg in the same Graafian follicle as in Fig. 3, showing its ectoplasm with numerous cortical granules, scattered mitochondria of various shapes and large lipid droplets. Inset : higher magnification of mitochondria showing well developed cristae and dense matrix.

Fig. 5. Electron micrograph of the corona cell of the same cumulus oophorus as in Fig. 3. Note well developed smooth endoplasmic reticulum with packed tubular cisternae, wider Golgi complex, active mitochondria, and more lysosomes and lipid droplets (see Pl. 1, Fig. 2). Inset: higher magnification of smooth endoplasmic reticulum. 
PLATE 1

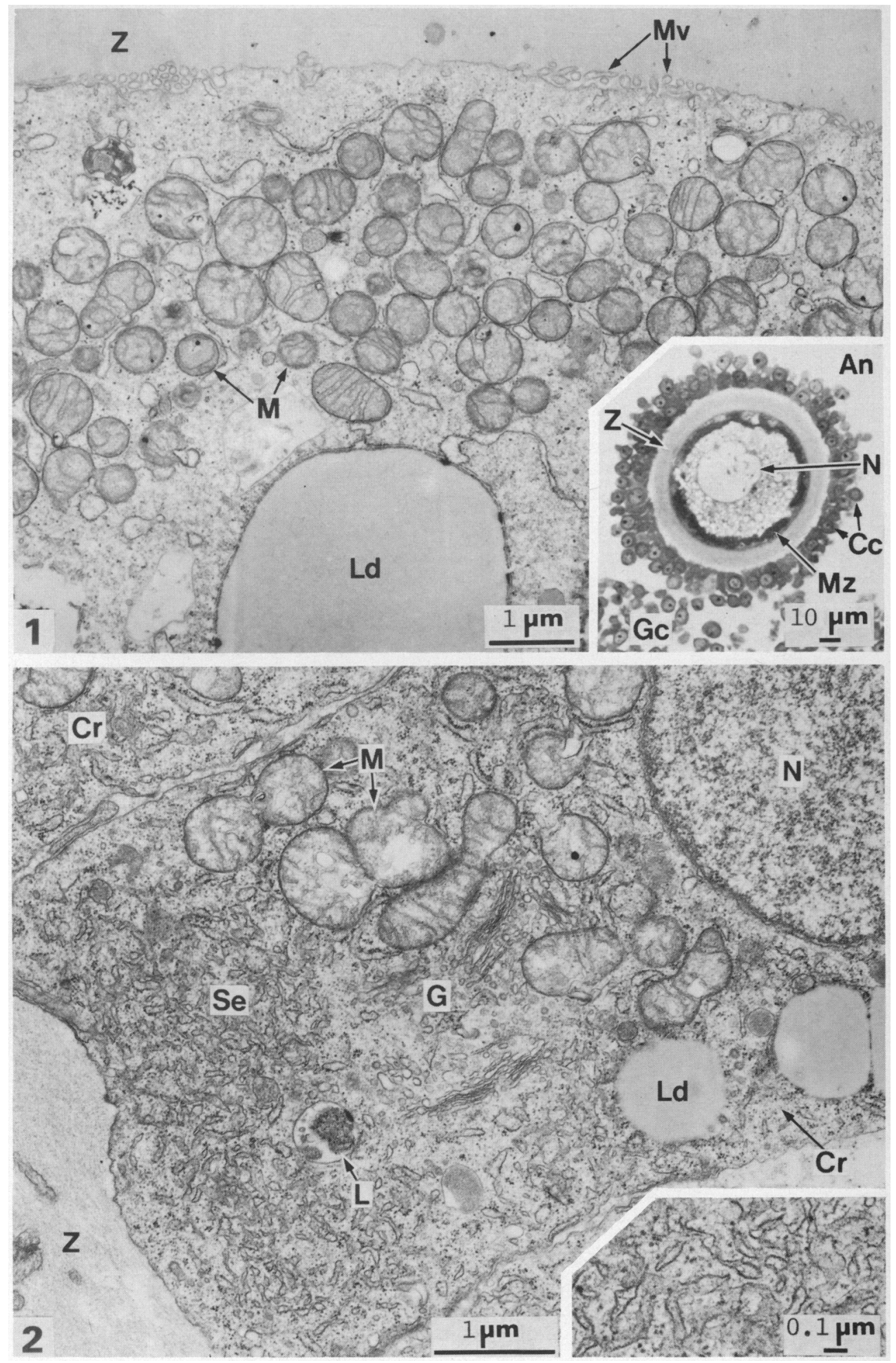

(Facing p. 122) 
PLATE 2

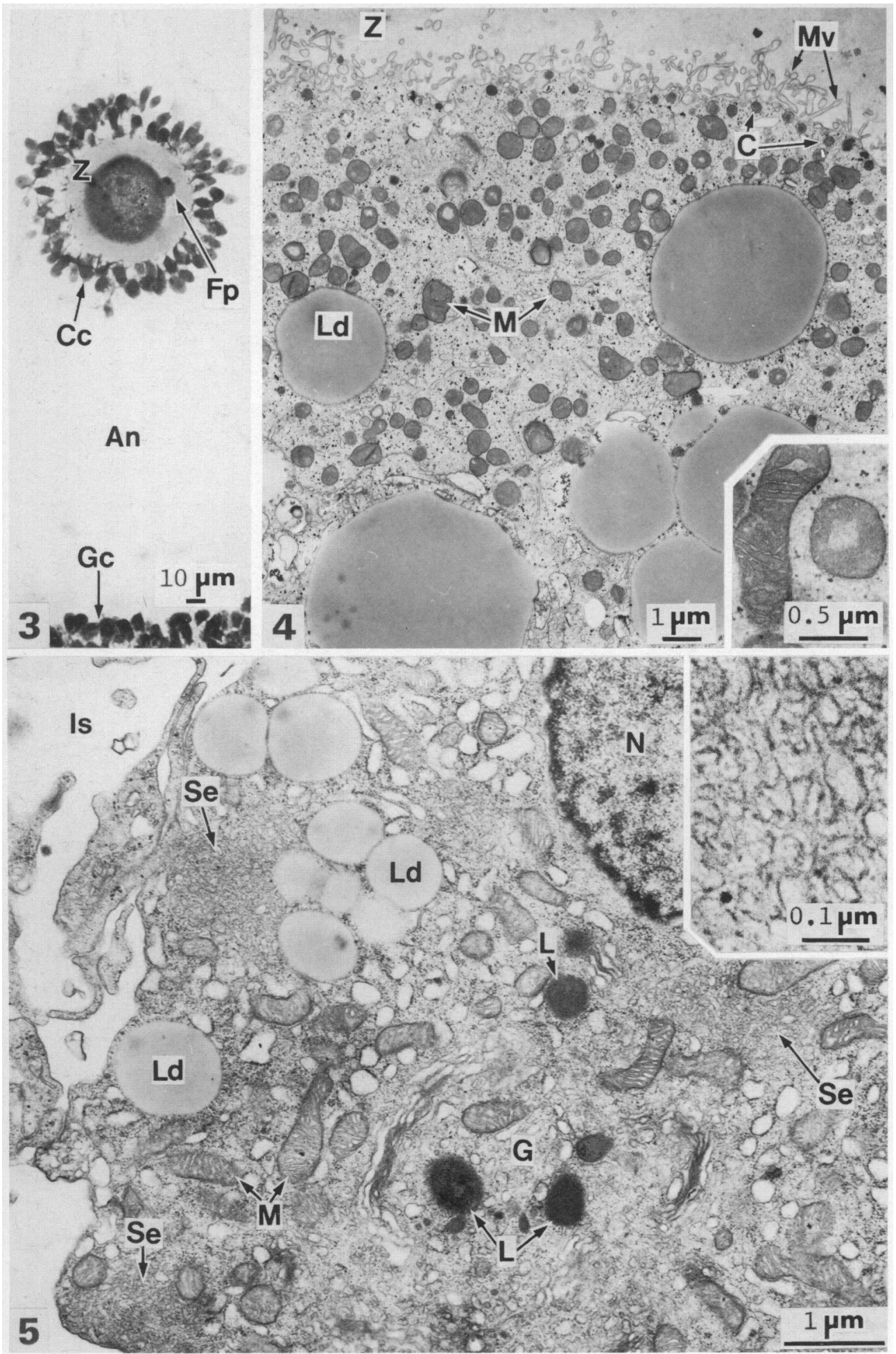


PLATE 3

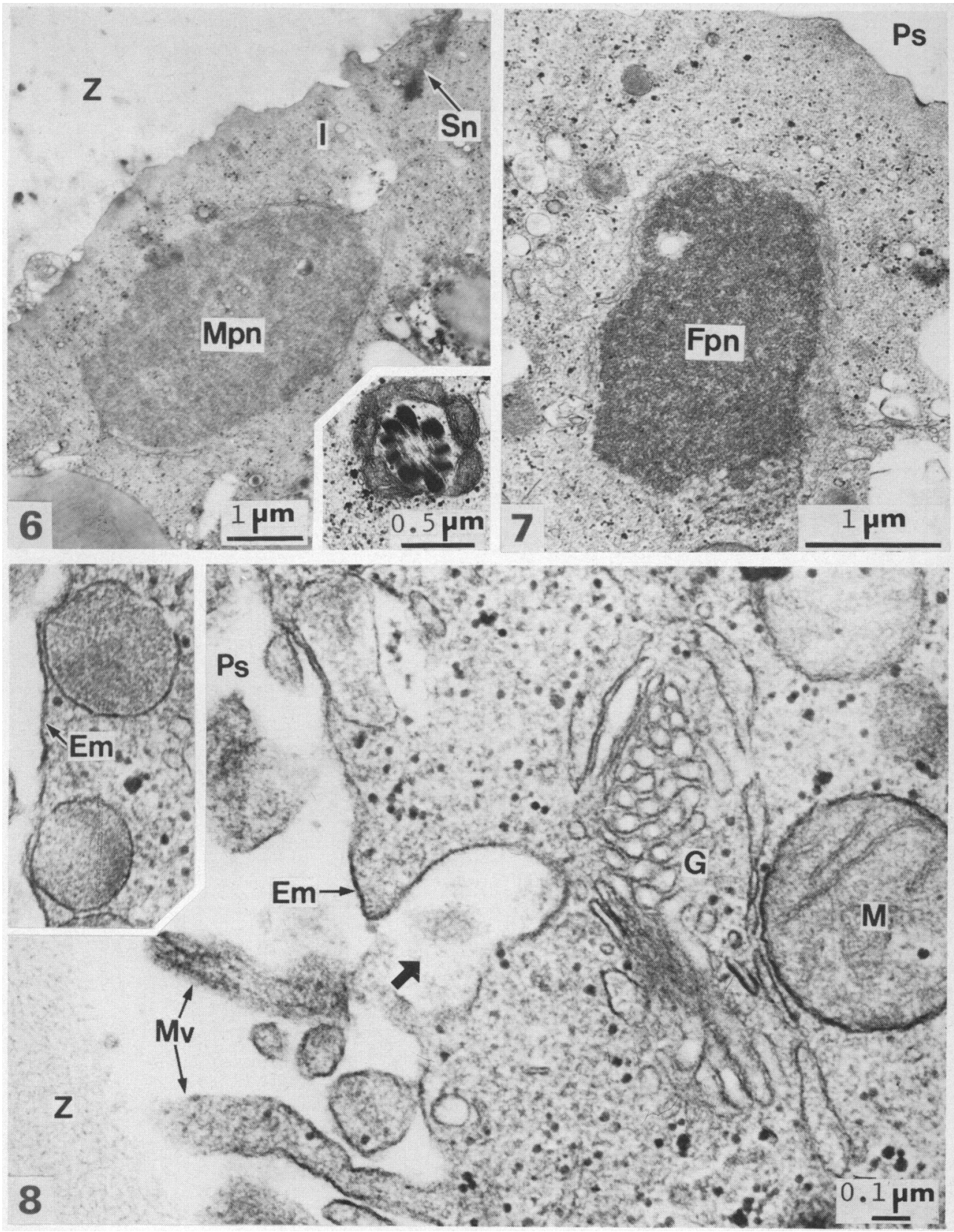

Figs 6 and 7. Electron micrographs showing an egg in an early stage of pronucleus formation (Bat G3). Fig. 6. A swelling male pronucleus and sperm neck in the incorporation cone devoid of microvilli. Inset : the sperm middle piece near the male pronucleus. Fig. 7. The female pronucleus with a chromatin mass, slightly apart from the male pronucleus.

Fig. 8. Electron micrograph showing part of the cortical reaction (large arrow) on the surface of the plasma membrane of the same egg as in Fig. 6. Inset : cortical granules in close contact with the plasma membrane. 


\section{PLATE 4}

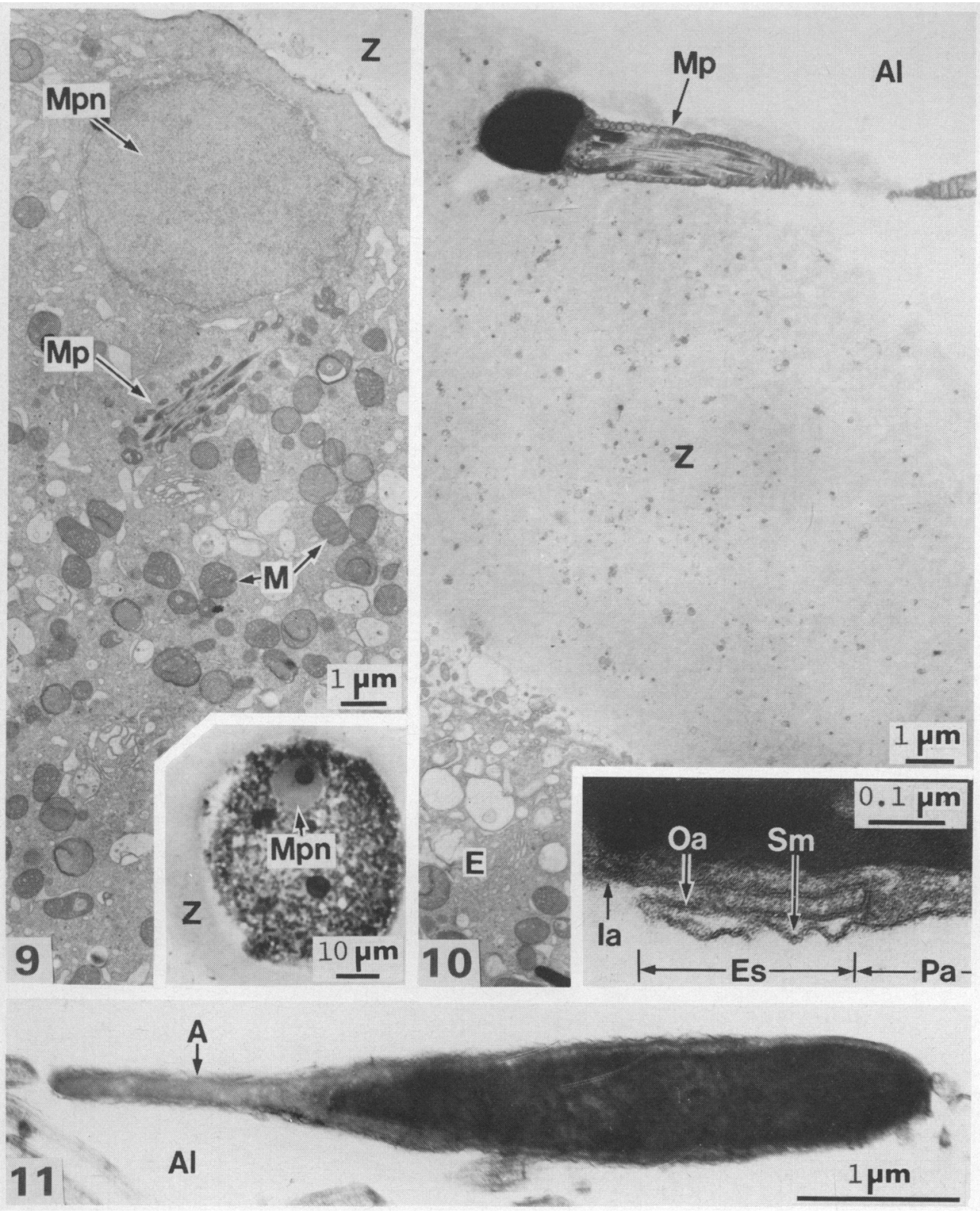

Fig. 9. Electron micrograph of an egg in a slightly advanced stage of pronucleus formation, showing the male pronucleus, sperm middle piece near it and abundant mitochondria spreading over the ooplasm (Bat G9). Inset: light micrograph of the egg showing the male pronucleus with a single large, round nucleolus.

Fig. 10. Electron micrograph of a second spermatozoon found in the superficial portion of the zona pellucida (Bat G9). Inset : higher magnification of the intact equatorial segment showing a slightly periodic structure between the inner and outer acrosomal membranes and fusion of the outer acrosomal and plasma membranes at the tip.

Fig. 11. Electron micrograph of an acrosome-intact spermatozoon found near a fertilized egg (Bat G4). 
Table 1. Prolonged survival of the Graafian follicle and fertilization in Japanese greater horseshoe bats

\begin{tabular}{|c|c|c|c|}
\hline Reproductive stage & Date captured & Bat* & Developmental stage of ovum \\
\hline Copulatory (before hibernation) & $\begin{array}{l}13 \text { October } 1969 \\
17 \text { October } 1980 \\
24 \text { October } 1970 \\
27 \text { October } 1983\end{array}$ & $\left.\begin{array}{l}\mathrm{C} 1 \dagger, \mathrm{C} 2 \dagger \\
\mathrm{C} 11 \dagger-\mathrm{C} 13 \\
\mathrm{C} 3 \dagger-\mathrm{C} 5 \\
\mathrm{C} 14, \mathrm{C} 15\end{array}\right\}$ & $\begin{array}{l}\text { Prophase of meiosis I } \\
\text { (pachytene or diplotene) }\end{array}$ \\
\hline $\begin{array}{l}\text { Preovulatory, without stigma } \\
\text { (in hibernation) }\end{array}$ & $\begin{array}{l}9 \text { January } 1978 \\
22 \text { January } 1980 \\
2 \text { April } 1980\end{array}$ & $\begin{array}{l}\text { C6 } \\
\text { C7 } \\
\text { C8-C10 }\end{array}$ & $\begin{array}{l}\text { Prophase of meiosis I } \\
\text { (pachytene or diplotene) }\end{array}$ \\
\hline $\begin{array}{l}\text { Preovulatory, with stigma } \\
\text { (at arousal) }\end{array}$ & $\begin{array}{l}2 \text { April } 1980 \\
3 \text { April } 1981 \\
5 \text { April } 1980\end{array}$ & $\begin{array}{l}\text { G1 } \\
\text { G10 } \\
\text { G7 }\end{array}$ & $\begin{array}{l}\text { Anaphase of meiosis I } \\
\text { Metaphase of meiosis I } \\
\text { Metaphase of meiosis II }\end{array}$ \\
\hline
\end{tabular}

Fertilized

\begin{tabular}{lrll} 
& 2 April 1980 & G3 & Early pronucleus formation \\
& 2 April 1980 & G4 & More advanced pronucleus formation \\
One-cell (at arousal) & 3 April 1981 & G8 & Anaphase of meiosis II \\
& 3 April 1981 & G9 & Slightly advanced pronucleus formation \\
& 3 April 1981 & G11 & More advanced pronucleus formation \\
Cleavage (after arousal) & 14 April 1970 & C16 & 32-celled morula \\
\hline
\end{tabular}

* Group $\mathrm{C}$ and Group $\mathrm{G}$ represent control bats and hormone-treated bats, respectively. The data on Bats G2, G5 and $\mathrm{G} 6$ are not included because of preparation failures.

$\dagger$ Unmated bats.

\section{Copulatory stage before hibernation}

Mated Bats C4, C5 and C12-C15 and unmated Bats C1-C3 and C11 collected in mid- or late October always had a few antral follicles (diam. $>350 \mu \mathrm{m}$ ), only in the right ovary. Of these antral follicles, one (diam. $\sim 450 \mu \mathrm{m}$ ) containing an ovum with a germinal vesicle at the pachytene or diplotene stage in prophase of meiosis I (resting stage) was destined to rupture in the following spring (mid-April). The cumulus oophorus was joined to the granulosa layer by a cellular retinaculum; the cumulus cells had not yet dispersed (Pl. 1, Fig. 1, inset) and some were in mitotic division. The ovum ectoplasm was crowded with abundant spherical mitochondria with few cristae and a moderately electron-dense matrix, and with many large lipid droplets inside the mitochondrial zone (Pl. 1, Fig. 1). The cumulus cells contained a considerable amount of smooth endoplasmic reticulum with expanded cisternae, a narrow Golgi body, mitochondria with a few cristae and electron-sparse matrix, a few lysosomes and lipid droplets (Pl. 1, Fig. 2 and inset). The remaining antral follicles showed signs of atresia characterized by pycnosis of degenerating granulosa cells.

\section{Preovulatory stage without the stigma in hibernation}

In Bats $\mathrm{C} 6-\mathrm{C} 10$ in hibernation, the single Graafian follicle looked the same as in the copulatory stage, except for the increase in size (diam. $\sim 540-\sim 630 \mu \mathrm{m}$ ). The remaining antral follicles became more atretic during hibernation.

\section{Preovulatory stage with the stigma at arousal}

Each right ovary of Bats G10, G1 and G7 treated with PMSG and hCG had the stigma visible as a swollen translucent area on the ovarian surface. In Bats G10 and G1 the oocytes were in metaphase and anaphase of meiosis I, respectively, and in Bat G7 it was in metaphase of the meiosis II accompanied by the first polar body. The Graafian follicle (diam. $\sim 800 \mu \mathrm{m}$ ) varied in 
morphology with progress of the meiotic division. In Bat $\mathrm{G} 7$ the cumulus oophorus had completely separated from the granulosa layer, and most of the cumulus and granulosa cells were dispersed (Pl. 2, Fig. 3). Cortical granules (diam. $\sim 0.35 \mu \mathrm{m}$ ) had appeared, in large numbers near the egg surface which had numerous microvilli. Abundant mitochondria of various shapes and with well developed cristae and a dense matrix became scattered in a wider area of the ectoplasm which contained many large lipid droplets and a few glycogen granules (Pl. 2, Fig. 4 and inset).

Both the cumulus and the granulosa cells showed characteristic features of steroid-producing cells (the so-called preovulatory luteinization) in that there was a well developed smooth endoplasmic reticulum with packed tubular cisternae, wide Golgi complex and mitochondria with many cristae and a dense matrix, and an increase of lysosomes and lipid droplets (Pl. 2, Fig. 5 and inset).

\section{Fertilized stage at arousal}

Bats 3, 4, 8, 9 and 11 of Group $\mathrm{G}$ each contained a fertilized (1-celled) ovum and Bat $\mathrm{C} 16$ had a morula in the right ampulla. In Bat G8 the ovum, obtained just after sperm penetration, had a nucleus in anaphase of meiosis II. The egg of Bat $\mathrm{G} 3$ was in the early stage of pronucleus formation; a slightly swelling male pronucleus in the process of chromatin dispersion, the sperm neck and middle piece (Pl. 3, Fig. 6 and inset) were present in an incorporation cone which was devoid of microvilli, and the female pronucleus with a chromatin mass was found slightly apart from the male one (PI. 3, Fig. 7). Although the cortical reaction had occurred, some cortical granules still remained in close contact with the egg plasma membrane, and the Golgi complex was conspicuous in the ectoplasm (Pl. 3, Fig. 8 and inset).

The ovum of Bat G9 had slightly advanced pronuclei and a sperm middle piece near the male pronucleus which had a single large, round nucleolus; abundant mitochondria were spread throughout the ooplasm but lipid droplets had decreased in number at this stage (Pl. 4, Fig. 9 and inset). A second spermatozoon which had lost the acrosome cap but still maintained the equatorial segment was recognized in the superficial portion of the zona pellucida (Pl. 4, Fig. 10); the inner and outer acrosomal membranes of the equatorial segment remained intact, separated by electrondense material. The outer acrosomal membrane was continuous with the plasma membrane at the tip (Pl. 4, Fig. 10, inset).

Each ovum of Bats G4 and G11 had more advanced pronuclei. In Bat G4, a second spermatozoon devoid of both the acrosome cap and the equatorial segment was found in a slanting position about a third of the way through the zona pellucida. A few spermatozoa found near the fertilized ovum in the ampulla still had an intact acrosome cap (PI. 4, Fig. 11). In Bat C16 (after arousal), a 32-celled morula also had a second spermatozoon about one third through the zona pellucida. A second spermatozoon was not found in the zona pellucida of the 3 ova of Bats G3, G8 and G11. In spite of careful examinations of serial sections, no spermatozoon was detected in the perivitelline spaces of these 6 fertilized ova.

\section{Discussion}

Carbohydrates play an important role as a nutrient source for ovarian follicles in mammals (Bjersing, 1977). In some hibernating bats of the subfamily Vespertilioninae (Vespertilionidae), polysaccharides (e.g. glycogen) in the cumulus cells have been regarded as an important aspect of the prolonged survival of the Graafian follicles during hibernation (Wimsatt \& Kallen, 1957; Wimsatt \& Parks, 1966, for the little brown bat, Myotis lucifugus; Uchida \& Mōri, 1977, for the Japanese house-dwelling bat, Pipistrellus abramus) as well as for sperm storage in the female reproductive tract (Nakano, 1928; Racey, 1979; Crichton, Krutzsch \& Wimsatt, 1981). In the Japanese greater horseshoe bat (Rhinolophinae, Rhinolophidae), however, the large amount of lipids in both the 
ovum and the cumulus cells is the presumed source of energy-rich substances throughout hibernation.

There seem to be two different devices to protect mammalian eggs, against polyspermy, i.e. the zona block, found in sheep and dogs (Braden, Austin \& David, 1954), golden hamsters (Austin \& Braden, 1956; Barros \& Yanagimachi, 1971; Yanagimachi, 1977) and cows (Brackett, Oh, Evans \& Donawick, 1980), and the vitelline block found in the rabbit (Austin \& Braden, 1956) and Japanese long-fingered bat (Mōri \& Uchida, 1981). Both mechanisms are found in the mouse and rat (Austin $\&$ Braden, 1956). In the pig, however, spermatozoa were found in the perivitelline space of $24 / 208$ recovered eggs and polyspermy occurred in 6/143 fertilized ova (Hunter \& Dziuk, 1968), indicating partial failure of both devices. In Japanese greater horseshoe bats, the block to polyspermy seems to reside in the zona pellucida as in the sheep, dog, hamster and cow, because no spermatozoon was detected in the perivitelline space of the 6 fertilized ova at stages from anaphase of meiosis II to the 32-celled morula, although a second spermatozoon was seen in the zona pellucida of 3 of the eggs. The numbers of bats in this study are low, but if the block does not reside in the zona, spermatozoa should have been found in the perivitelline space of the 6 fertilized ova, as in 20 fertilized ova at the stage from sperm fusion to 32-celled morula in Japanese long-fingered bats (Mōri \& Uchida, 1981, 1982 ) and as in $4 / 28$ tubal ova of the little sac-winged bat, Peropteryx kappleri (Rasweiler, 1982).

We thank Dr S. Arai of this Laboratory and Dr T. Kuramoto of the Akiyoshi-dai Museum of Natural History for their help in collecting specimens; and Professor E. W. Jameson, Jr, University of California for comments on the manuscript.

\section{References}

Austin, C.R. \& Braden, A.W.H. (1956) Early reaction of the rodent egg to spermatozoon penetration. J. exp. Biol. 33, 358-365.

Barros, C. \& Yanagimachi, R. (1971) Induction of zona reaction in golden hamster eggs by cortical granule material. Nature, Lond. 233, 268-269.

Bjersing, L. (1977) Ovarian histochemistry. In The Ovary, 2nd edn, vol. 1, ch. 7, pp. 303-391. Eds S. Zuckerman \& B. J. Weir. Academic Press, New York.

Brackett, B.G., Oh, Y.K., Evans, J.F. \& Donawick, W.J. (1980) Fertilization and early development of cow ova. Biol. Reprod. 23, 189-205.

Braden, A.W.H., Austin, C.R. \& David, H.A. (1954) The reaction of the zona pellucida to sperm penetration. Aust. J. biol. Sci. 7, 391-409.

Crichton, E.G., Krutzsch, P.H. \& Wimsatt, W.A. (1981) Studies on prolonged spermatozoa survival in Chiroptera. I. The role of uterine free fructose in the spermatozoa storage phenomenon. Comp. Biochem. Physiol. 70A, 387-395.

Fries, S. (1879) Ueber die Fortpflanzung der einheimischen Chiropteren. Zool. Anz. 2, 355-357.

Hunter, R.H.F. \& Dziuk, P.J. (1968) Sperm penetration of pig eggs in relation to the timing of ovulation and insemination. J. Reprod. Fert. 15, 199-208.

Matthews, L.H. (1937) The female sexual cycle in the British horseshoe bats, Rhinolophus ferrumequinum insulanus Barrett-Hamilton and $R$. hipposideros minutus Montagu. Trans. zool. Soc. Lond. 23, 224-267.

Mōri, T. \& Uchida, T.A. (1981) Ultrastructural observations of fertilization in the Japanese long-fingered bat, Miniopterus schreibersii fuliginosus. J. Reprod. Fert. 63, 231--235.
Mōri, T. \& Uchida, T.A. (1982) Changes in the morphology and behaviour of spermatozoa between copulation and fertilization in the Japanese longfingered bat, Miniopterus schreibersii fuliginosus. J. Reprod. Fert. 65, 23-28.

Mōri, T., Oh, Y.K. \& Uchida, T.A. (1982) Sperm storage in the oviduct of the Japanese greater horseshoe bat, Rhinolophus ferrumequinum nippon. J. Fac. Agric., Kyushu Univ. 27, 47-53.

Nakano, O. (1928) Ueber die Verteilung des Glykogens bei den zyklischen Veränderungen in den Geschlechtsorganen der Fledermaus. Und über die Nahrungsaufnahme der Spermien in dem weiblischen Geschlechtswege. Folia anat. jap. 6, 777-828.

Oh, Y.K., Möri, T. \& Uchida, T.A. (1983) Studies on the vaginal plug of the Japanese greater horseshoe bat, Rhinolophus ferrumequinum nippon. J. Reprod. Fert. 68, 365-369.

Oura, C. \& Usuku, G. (1976) Ultrathin-sectioning of the limited area for electron microscopy from serial one micron sections. Okajima Fol. anat. jap. 52, 331340.

Racey, P.A. (1975) The prolonged survival of spermatozoa in bats. In The Biology of the Male Gamete, pp. 385-416. Eds J. G. Duckett \& P. A. Racey. Academic Press, London.

Racey, P.A. (1979) The prolonged storage and survival of spermatozoa in Chiroptera. J. Reprod. Fert. 56, 391402.

Rasweiler, J.J., IV (1982) The contribution of observations on early pregnancy in the little sac-winged bat, Peropteryx kappleri, to an understanding of the evolution of reproductive mechanisms in monovular bats. Biol. Reprod. 27, 681-702. 
Uchida, T.A. \& Mōri, T. (1977) Hibernation. Metabolism, Tokyo 14, 154-156. [In Japanese.]

Uchida, T.A., Mōri, T. \& Oh, Y.K. (1984) Sperm invasion of the oviducal mucosa, fibroblastic phagocytosis and endometrial sloughing in the Japanese greater horseshoe bat, Rhinolophus ferrumequinum nippon. Cell Tissue Res. 236, 327-331.

Wimsatt, W.A. \& Kallen, F.C. (1957) The unique maturation response of the Graafian follicles of hibernating vespertilionid bats and the question of its significance. Anat. Rec. 129, 115-132.
Wimsatt, W.A. \& Parks, H.F. (1966) Ultrastructure of the surviving follicle of hibernation and of the ovumfollicle cell relationship in the vespertilionid bat Myotis lucifugus. Symp. zool. Soc., Lond. 15, 419-454.

Yanagimachi, R. (1977) Specificity of sperm-egg interaction. In Immunobiology of Gametes, pp. 255-289. Eds M. Edidin \& M. H. Johnson. Cambridge University Press.

Received 26 March 1984 